\title{
Malignant transformation of cervical ostochondroma in patient with hereditary multiple exostoses (HME): Case report and review of the literature
}

\author{
A. Landi ${ }^{1}$, P. Rocco $^{1}$, C. Mancarella ${ }^{1}$, R. Tarantino ${ }^{1}$, A. Raco ${ }^{2}$ \\ 1. Department of Neurology and Phsichiatry, Division of Neurosurgery, University of Rome Sapienza, Policlinico Umberto \\ I, Rome. 2. Department of Neurosurgery, University of Rome Sapienza, S. Andrea Hospital, Rome.
}

Correspondance: Alessandro Landi. Address: Department of Neurosurgery, University of Rome "Sapienza", Viale del Policlinico 155, 00100 Rome, Italy. Telephone: 39-329-0641-772. E-mail: link55@libero.it

Received: October 14, 2011

Accepted: April 5, 2012

Published: June 1, 2012

DOI : $10.5430 /$ jst.v2n3p63

URL: http://dx.doi.org/10.5430/jst.v2n3p63

\begin{abstract}
Objectives: Hereditary multiple exosostes (HME) is a disorder characterized by the presence of multiple osteochondromas of the bone. Spinal involvement is rare, represent roughly 3\% of cases and any portion of the vertebral body may be affected. Malignant transformation of the lesions is rare, but it is possible and is described in literature. Methods: We describe an unusual case of malignant transformation of a cervical osteochondromas arising from the articular complex, in a young girl affected by HME. The patient underwent surgery with a complete removal of the lesion, without any signs of recurrence seen at the MRI serial control at 3, 612 e 24 months. We analyzed the literature up to 2009 by focusing on the treatment and follow up.

Results: Surgical removal is indicated for symptomatic spinal osteochondormas. The suspicion of malignant transformation is indicated by the sudden growth of the lesion after puberty, the presence of pain and the worsening of the neurological symptoms.

Conclusions: In this case, radical surgery is imperative, given the close correlation with the malignant characteristics of the lesions, it is useful to have an extemporaneous histological examination. In the rare cases of malignant transformation, radical surgery is important for the prognosis and to prevent the progression of the lesions. If the complete removal is not possible, the therapy of choice is adjuvant radiotherapy.
\end{abstract}

\section{Key words}

Hereditary multiple exosostes, Cervical condrosarcoma, Surgery, Radiotherapy

\section{Introduction}

Hereditary multiple exostoses (HME) is the most common type of bone dysplasia, which was first described by Boyer in $1814^{[1-3]}$, characterized by the presence of osteochondromas and multiple exostoses of the long bones ${ }^{[3,4]}$. This disease is associated to the mutation of: WXT 1, on the long arm of chromosome 8; EXT 2 on the short arm of chromostome $19^{[2]}$. HME is an autosomal dominant bone disorder with incomplete penetrance ${ }^{[5]}$. Spinal involvement is rare, represent roughly $3 \%$ of cases and any portion of the vertebral body may be affected, anterior and posterior. Malignant degeneration is rare and represents $20 \%$ of the patients affected by $\mathrm{HME}^{[6]}$. We report an unusual case of malignant degeneration to 
grade I chondrosarcomas, of a cervical osteochondromas arising from C6-C7 articulation in a young girl affected by HME, and analyze the literature focusing on the treatment and follow up.

\section{Materials and methods}

\section{Case presentation}

30-year-old girl affected by HME, with multiple exostosis over the right elbow, the left knee and the cervical body of C6 on the right, diagnosed by XRay and histological examination since the age of 12 years during the removal of a symptomatic exostosis of the left knee. A positive family history for four cases of first-degree relatives affected by HME was found. She came to our attention in October 2007 because of the sudden presentation of a rounded, hard lesion, not painful, in the right side of the cervical region, near to the cervical lesion already known and studied by XRay serial exams and asymptomatic until now. The onset of symptoms was about 3 months, associated with a progressive worsening of the right cervical-brachialgia. A cervical gadolinium- MRI showed a rounded lesion arising from the right articular mass of C6, hyperintense on T1 weighted images with a small enhancing nodule after gadolinium administration (Figure 1). Neurological examination of the patient showed hypoesthesia and dysesthesia extending to the C5 dermatome on the right, with radiation of pain into the shoulder. Investigation with computed tomography (CT) of the cervical spine demonstrated hyperostosis of the C6 articular mass with extension in both vertebral foramen and foramen of conjugation, and showed osteolysis of the C6 joint on the right. In the light of the acuity and the progression of symptoms, associated to the post puberal age of the patient, surgical treatment was advised with the aim of complete removal of the lesion. In November 2007, the patient underwent to a complete C6 arthrectomy, decompression of the vertebral artery and of the ipsilateral nerve root, followed by posterior fixation with trans pedicle screws in C7 and T1 and screws in the articular masses in C3 and C4. The final histological examination confirmed the lesion to be an I grade chondrosarcomas. In the postoperative period the patient presented a complete regression of the pain and the paresthesia. A postoperative CT scan showed a complete removal of the lesion (Figure 2). A MRI and CT control at 12 months demonstrated no recurrence of the disease. Scintigraphy and PET examination performed at 12 months showed no pathological uptake (Figure 3). She performed a cervical MRI and CT scan with contrast at 24 months showing the absence of recurrence (Figure 4). The patient is actually symptom-free and neurologically intact.

Figure 1. A cervical MRI showing a rounded lesion arising from the right

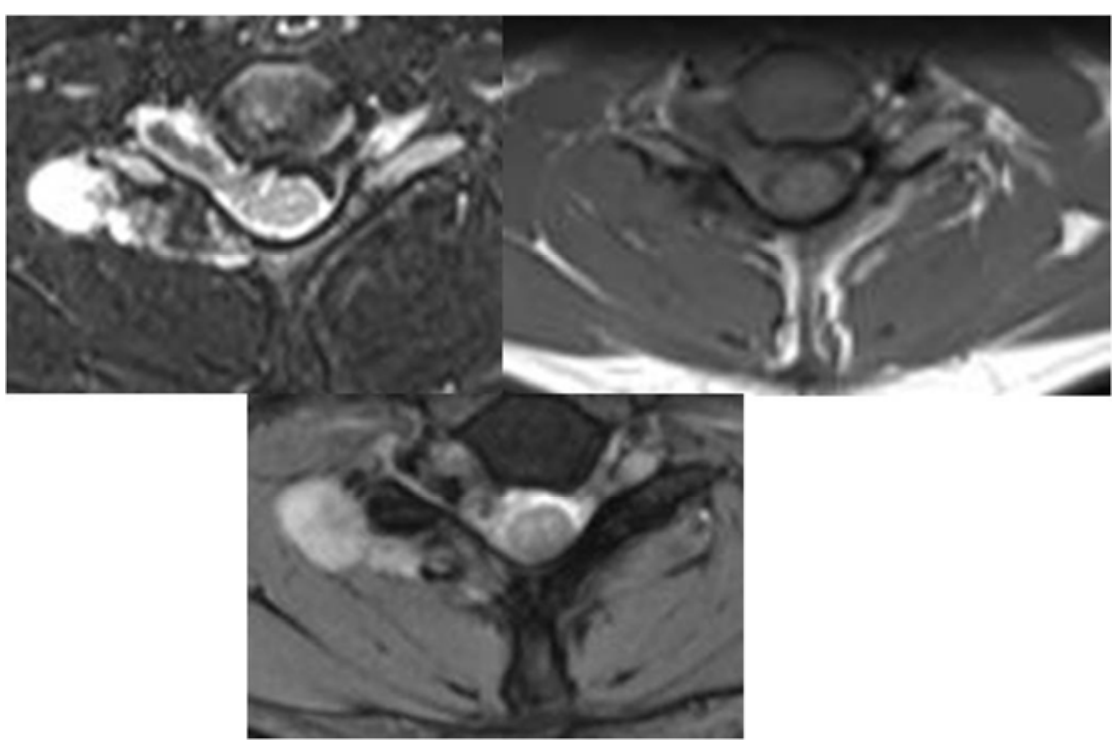
articular mass of C6 
Figure 2. A postoperative CT scan showing a complete removal of the lesion

Figure 3. Scintigraphy and PET examination at 12 months after surgery showing no pathological uptake

Figure 4 A cervical MRI at 24 months showing the absence of recurrence
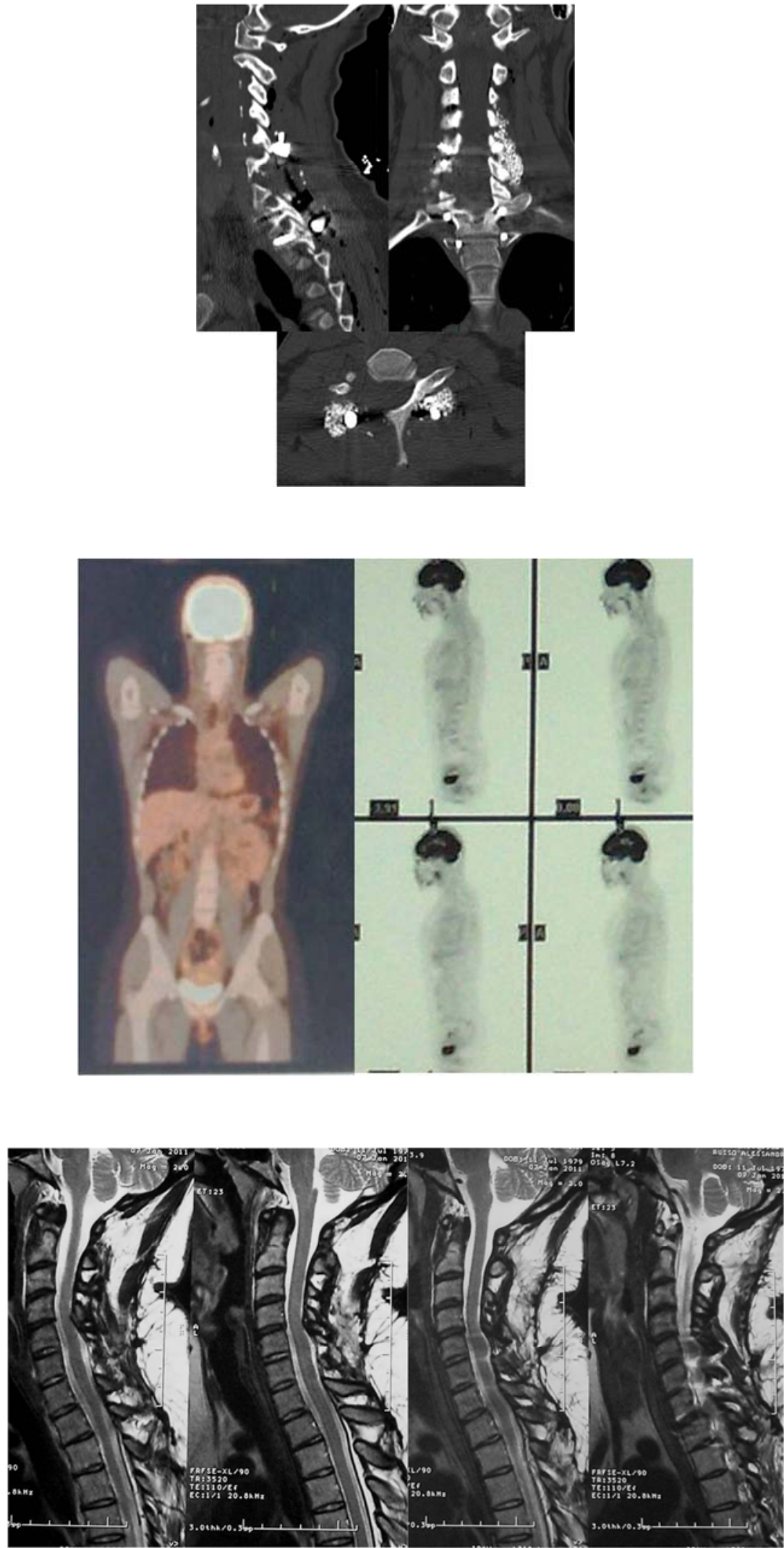


\section{Results}

A review of the literature since 1843 revealed 53 cases of vertebral osteochondromas and our case is the only one with malignant de generation to osteosarcoma of first grade. Reid in 1843 was the first to describe a case of cervical lesion associated to $\mathrm{HME}^{[16]}$. Ochsner in 1907 was the first to describe the treatment ${ }^{[17]}$. The age of the patients ranged from 7 to 58 years (mean age 20,6), valuable only on 45 patients. Most patients were male (M: $\mathrm{F}=2: 1$ ). In our review it was possible to determine a familiarity in 38 cases out of 53 documented, with a positive family history in 25 cases. The C2 level was the most attacked level (40\%), on 45 patients, and arose from the lamina and the pedicle (all together 77, 3\% of cases).

Table 1. Extensive review of the literature: Historic cohort

\begin{tabular}{|c|c|c|c|c|c|c|c|c|c|}
\hline Author & Year & Age & Gender & Level & Origin & Surgery & Outcome & Istology & Familiar history \\
\hline Reid $^{[16]}$ & 1843 & 30 & Male & $\mathrm{C} 2$ & Lamina & No & Died & Osteochondroma & $\mathrm{Nr}$ \\
\hline Ochsner $^{[17]}$ & 1907 & 23 & Male & $\mathrm{C} 2$ & Lamina & Yes & Improved & Osteochondroma & No \\
\hline Oberndof ${ }^{[18]}$ & 1910 & 19 & Male & C3 & NR & No & Died & Osteochondroma & No \\
\hline Slepian ${ }^{[19]}$ & 1951 & 33 & Male & C5-6 & Articular mass & Yes & Good & $\mathrm{Nr}$ & Yes \\
\hline Rose $^{[20]}$ & 1964 & 58 & Female & $\mathrm{C} 1$ & Odontoid & No & Died & Osteochondroma & $\mathrm{Nr}$ \\
\hline Carmel ${ }^{[21]}$ & 1968 & 13 & Female & $\mathrm{C} 2$ & Lamina pedicle & Yes & Good & Osetochondroma & Yes \\
\hline Chiurco $^{[22]}$ & 1970 & 16 & Male & $\mathrm{C} 0$ & Occipital bone & Yes & Died & Osteochondroma & No \\
\hline Sawada ${ }^{[23]}$ & 1970 & 18 & Male & $\mathrm{C} 4$ & Lamina & Yes & Good & Osteochondroma & Yes \\
\hline Vinstein ${ }^{[24]}$ & 1971 & 14 & Female & $\mathrm{C} 2$ & Lamina & Yes & Good & Osteochondroma & No \\
\hline Madigan ${ }^{[13]}$ & 1974 & 7 & Female & $\mathrm{C} 2$ & Lamina & Yes & Good & Osteochondroma & Yes \\
\hline Blaauw $^{[25]}$ & 1975 & 39 & Male & $\mathrm{C} 7$ & Lamina & Yes & $\mathrm{Nr}$ & Osteochondroma & $\mathrm{Nr}$ \\
\hline Jorge $^{[26]}$ & 1975 & 15 & Male & $\mathrm{C} 2$ & Lamina & Yes & Good & Osteochondroma & No \\
\hline Roman $^{[27]}$ & 1978 & 37 & Male & $\mathrm{C} 7$ & Lamina & Yes & Good & Osteochondroma & Yes \\
\hline Ferrari ${ }^{[28]}$ & 1979 & 23 & Male & $\mathrm{C} 2$ & Body & Yes & Good & Osteochondroma & Yes \\
\hline Singh ${ }^{[29]}$ & 1980 & 29 & Female & C5 & Lamina/pedicle & Yes & Died & Osteochondroma & Yes \\
\hline Palmer ${ }^{[30]}$ & 1980 & 22 & Male & C6 & Body & Yes & Good & Osteochondroma & No \\
\hline Misra $^{[31]}$ & 1983 & 25 & Male & $\mathrm{C} 4$ & Lamina & Yes & Good & Osteochondroma & No \\
\hline Omori $^{[32]}$ & 1983 & 22 & Male & $\mathrm{C} 2$ & Lamina & Yes & Good & Osteochondroma & No \\
\hline O’Connor $^{[33]}$ & 1984 & 24 & Female & $\mathrm{C} 5$ & Lamina & Yes & Good & Osteochondroma & Yes \\
\hline Gottlieb $^{[14]}$ & 1986 & 31 & Male & $\mathrm{C} 4$ & Lamina & Yes & Improved & Osteochondroma & Yes \\
\hline Johnston ${ }^{[34]}$ & 1988 & 15 & Male & $\mathrm{C} 2$ & Lamina & Yes & Good & Osteochondroma & Yes \\
\hline Wen ${ }^{[3]}$ & 1989 & 23 & Female & $\mathrm{C} 1$ & Posterior ach & Yes & Good & Osteochondroma & Yes \\
\hline Tully ${ }^{[35]}$ & 1989 & 12 & Female & C5 & Body & Yes & Improved & Osteochondroma & Yes \\
\hline Shapiro ${ }^{[5]}$ & 1990 & 11 & Male & $\mathrm{C} 2$ & Lamina & Yes & Good & Osteochondroma & Yes \\
\hline Nunez ${ }^{[36]}$ & 1990 & 15 & Male & $\mathrm{C} 2$ & Posterior arc & Yes & Good & Osteochondroma & Yes \\
\hline Anton ${ }^{[37]}$ & 1990 & 15 & Female & C6 & Lamina & Yes & $\mathrm{Nr}$ & Osteochondroma & Yes \\
\hline Moriwaka ${ }^{[38]}$ & ] 1990 & 9 & Male & C7-T1 & Pedicle/body & Yes & Good & Osteochondroma & No \\
\hline Bhojraj $^{[39]}$ & 1993 & 14 & Female & C3 & Lamina & Yes & Good & $\mathrm{Nr}$ & $\mathrm{Nr}$ \\
\hline Eder $^{[40]}$ & 1993 & 7 & Female & $\mathrm{C} 2$ & Posterior arc & Yes & Improved & Osteochondroma & Yes \\
\hline Barros $^{[41]}$ & 1995 & 16 & Female & $\mathrm{C} 1$ & Anterior arc & Yes & Good & Osteochondroma & Yes \\
\hline Atabay ${ }^{[1]}$ & 1996 & 17 & Male & $\mathrm{C} 2-4$ & Lamina & Yes & Good & Osteochondroma & Yes \\
\hline Labram $^{[4]}$ & 1996 & 9 & Male & $\mathrm{C} 2$ & Lamina & Yes & Good & Osteochondroma & Yes \\
\hline Labram $^{[4]}$ & 1996 & 45 & Male & C5 & Lamina & Yes & Good & Osteochondroma & $\mathrm{Nr}$ \\
\hline
\end{tabular}


Table 1. (Continued)

\begin{tabular}{|c|c|c|c|c|c|c|c|c|c|}
\hline Robbins ${ }^{[11]}$ & 1996 & 39 & Male & $\mathrm{C} 5$ & Lamina & Yes & Improved & Osteochondroma & Yes \\
\hline Robbins ${ }^{[11]}$ & 1996 & 15 & Male & $\mathrm{C} 3$ & Lamina & Yes & Good & Osteochondroma & Yes \\
\hline Ergun $^{[42]}$ & 1997 & 16 & Male & $\mathrm{C} 5-6$ & Pedicle/joint & Yes & Good & Osteochondroma & Yes \\
\hline Mikawa ${ }^{[43]}$ & 1997 & 17 & Male & $\mathrm{C} 7$ & Lamina/pedicle & Yes & Good & Osteochondroma & No \\
\hline $\operatorname{Oga}^{[44]}$ & 2000 & 13 & Male & C3 & Lamina & Yes & Good & Osteochondroma & Yes \\
\hline Cirak $^{[45]}$ & 2002 & 52 & Male & $\mathrm{C} 2$ & Body & Yes & Good & Osteochondroma & Yes \\
\hline Korinth ${ }^{[6]}$ & 2004 & 12 & Male & C2 & Posterior arc & Yes & Good & Osteochondroma & $\mathrm{Nr}$ \\
\hline Rohde ${ }^{[46]}$ & 2004 & 12 & Male & $\mathrm{C} 2$ & Lamina & Yes & Good & Osteochondroma & Yes \\
\hline Chooi $^{[10]}$ & 2005 & 23 & Female & $\mathrm{C} 1$ & Posterior arc & Yes & Good & Osteochondroma & Yes \\
\hline Miyamoto ${ }^{[47]}$ & 2005 & 23 & Male & $\mathrm{C} 2$ & Pedicle & Yes & Good & Osteochondroma & $\mathrm{Nr}$ \\
\hline Giudicissi-Filho $^{[9]}$ & 2006 & 18 & Female & C7 & Lamina & Yes & Good & Osteochondroma & No \\
\hline Roach $^{[48]}$ & 2010 & $\mathrm{Nr}$ & $\mathrm{Nr}$ & $\mathrm{Nr}$ & Body & Yes & $\mathrm{Nr}$ & Osteochondroma & $\mathrm{Nr}$ \\
\hline Roach $^{[48]}$ & 2010 & $\mathrm{Nr}$ & $\mathrm{Nr}$ & $\mathrm{Nr}$ & Body & Yes & $\mathrm{Nr}$ & Osteochondroma & $\mathrm{Nr}$ \\
\hline Roach $^{[48]}$ & 2010 & $\mathrm{Nr}$ & $\mathrm{Nr}$ & $\mathrm{Nr}$ & Lamina & Yes & $\mathrm{Nr}$ & Osteochondroma & $\mathrm{Nr}$ \\
\hline Roach $^{[48]}$ & 2010 & $\mathrm{Nr}$ & $\mathrm{Nr}$ & $\mathrm{Nr}$ & Lamina & Yes & $\mathrm{Nr}$ & Osteochondroma & $\mathrm{Nr}$ \\
\hline Roach $^{[48]}$ & 2010 & $\mathrm{Nr}$ & $\mathrm{Nr}$ & $\mathrm{Nr}$ & Lamina & Yes & $\mathrm{Nr}$ & Osteochondroma & $\mathrm{Nr}$ \\
\hline Roach $^{[48]}$ & 2010 & $\mathrm{Nr}$ & $\mathrm{Nr}$ & $\mathrm{Nr}$ & Lamina & Yes & $\mathrm{Nr}$ & Osteochondroma & $\mathrm{Nr}$ \\
\hline Roach $^{[48]}$ & 2010 & $\mathrm{Nr}$ & $\mathrm{Nr}$ & $\mathrm{Nr}$ & Lamina & Yes & $\mathrm{Nr}$ & Osteochondroma & $\mathrm{Nr}$ \\
\hline Roach $^{[48]}$ & 2010 & $\mathrm{Nr}$ & $\mathrm{Nr}$ & $\mathrm{Nr}$ & Lamina & Yes & $\mathrm{Nr}$ & Osteochondroma & $\mathrm{Nr}$ \\
\hline Raco & 2010 & 30 & Female & C5-c6 & Articular mass & Yes & Good & Cohondrosarcoma & Yes \\
\hline
\end{tabular}

\section{Discussion}

Hereditary multiple exostoses is a genetically heterogeneuous disease caused by the mutation of three loci: Ext1, on chromosome 8q24, Ext2 on 11p11, 11p12 and Ext3 on the short arm of chromosome $19^{[5]}$. The gene EXT products esostosin, endoplasmic reticulum localized glycoproteins which form a complex expressed at the cell surface that is active in the growth plate during endochondral bone formation ${ }^{[7,8]}$. Hereditary multiple exostoses HME is diagnosed by clinical criteria: 1) at least 2 radiologically documented osteocondromas in the juxta-epiphyseal region of the long bones and family history; 2) genetic criteria: Mutation of an EXT gene ${ }^{[8,9]}$. This disease is characterized by the progressive increase in the number of exostoses from generation to generation, and the progressive increase in size of the lesions ${ }^{[9]}$. The growth ceases with skeletal maturation. Clinical findings are usually skeletal deformities due to shortening of bones and bowing of the legs, exostoses and scoliosis ${ }^{[7,8]}$. Spinal involvement of solitary osteochondromas is between $1 \%$ and $4 \%$, whereas in patients with HME, the involvement of the vertebra column occurs in approximately $7 \%$ to $9 \%{ }^{[2,9-11]}$. Malignant transformation may occur in up to $1-5 \%$ of patients with HME ${ }^{[12,13]}$. The suspicion of secondary chondrosarcoma is indicated by growth of the tumor after puberty, the presence of pain, or a thickness over $1 \mathrm{~cm}$ of the cartilaginous cap ${ }^{[9]}$. The malignant transformation is associated with chromosomal instability and loss of heterozygosity of the EXT genes ${ }^{[7-9]}$. In cases of malignant transformation a surgical treatment is indicated with a complete removal of the lesion, with resection margins free of disease ${ }^{[9]}$. In the cases in which the excision of the lesion is total, the prognosis is generally good. The lesions localized often posteriorly because there are the secondary centers of ossifications, the sites of bone growth $^{[9,14,15]}$.

Our case is the only one described in the literature in which the lesion arises from the articular mass. From the analysis of the literature, 43 patients were evaluated during follow up and 5 of them died. Of the 5 patients died, 3 didn't undergo surgery. Moreover, of them died, in 3 cases symptoms appeared acutely with fast progression; just one of them was treated 
and all of them died. These findings, in relation to the excellent follow-up of the remaining 38 patients analyzed, show a close correlation between the acuity of symptoms and prognosis, demonstrating that an acute progression of symptoms is associated with a significantly more unfavorable prognosis, probably indicative of greater aggressiveness of the lesion. It is also important to underline that the age of onset of symptoms in 3 patients with acute and worsening symptoms, is greater than 29 years ( $29 \mathrm{yr}, 30 \mathrm{yr}$ and $58 \mathrm{yr}$ ), which confirms the hypothesis that this event, in post-pubertal age, is the result of an increased aggressiveness of the lesion, since the growth of typical HME osteochondromas ceases with skeletal maturation, then around 20-22 yrs for man and 17-20 yrs for woman.

50 Patients, our included, underwent surgery, but only for 40 cases the postoperative outcome is known: Thirty-three patients had good recovery with postoperative remission, 5 patients had improvement of symptoms with minimal residual symptoms, while only 2 cases died during the follow-up.

In relation to the benign nature of the lesions, the actions proposed in the literature are decompression (Laminectomy or cervical laminoplasty). These actions can then be completed with anterior or posterior stabilization. Clearly, in the cases in which the removal of the lesion has to be total, a contextual stabilization is asked ${ }^{[9]}$.

Radiological control as scintigraphy and PET can be useful to identify additional lesions throughout the skeleton as ipercaptant areas, but the gold standard for the diagnosis remains the MRI and CT scan ${ }^{\text {[7, 8, 49-51] }}$.

Radiation therapy seems to have an important role when the complete surgical removal in not possible, as orthopedic studies report ${ }^{[7,8,49-51]}$.

\section{Conclusion}

The malignant transformation of osteochondromas in patient affected with HME is rare but possible. This possibility can be suspected when there is a rapid growth of the lesion and a progressive worsening of symptoms, usually in adulthood. These lesions require surgical removal in order to halt the progression of the disease. Radiation therapy seems to have an important role when the complete surgical removal in not possible, an event nor uncommon in case of cervical lesions.

\section{Consent}

Written informed consent was obtained from the patient for publication of this case report and any accompanying images. A copy of the written consent is available for review by the Editor-in-Chief of this journal.

\section{Conflict of interest}

The authors declare that they have no competing interests.

\section{Acknowledgement}

RT performed the surgical procedure, participated in the drafting of the manuscript. AL participated in the surgical procedure and in the drafting of the manuscript. PR participated in the research of the literature. CM participated in the English translation of the manuscript. AR conceived of the study, and participated in its design and coordination and helped to draft the manuscript. All authors read and approved the final manuscript.

\section{References}

[1] Atabay H, Kuyucu Y, Korkmaz O, Iplikcioglu AC: Myelopathy due to hereditary multiple exostoses: CT and MR studies. Clin Neurol Neurosurg 1996;98(2):186-88. http://dx.doi.org/10.1016/0303-8467(96)00005-4 
[2] Solomon L: Hereditary multiple exostosis: Am Hum Genet 1964;16:351-63.

[3] Wen DY, Bergman TA, Haines SJ: Acute cervical myelopathy from hereditary multiple exostoses: Case report. Neurosurgery 1989;25(3):472-75. 2.

[4] Labram EK, Mohan J: Diaphyseal aclasis with spinal cord compression. Report of two cases and review of the literature. J Neurosurg 1996;84(3):518-21. PMid:8609568 http://dx.doi.org/10.3171/jns.1996.84.3.0518

[5] Shapiro SA, Javid T, Putty T: Osteochondroma with cervical cord compression in hereditary multiple exostoses. Spine 1990;15(6):600-602. PMid:2205931 http://dx.doi.org/10.1097/00007632-199006000-00033

[6] Korinth MC, Ramaekers VT, Rohde V: Cervical cord exostosis compressing the axis in a boy with hereditary multiple exostoses. Case illustration. J Neurosurg 2004;100 (2 Suppl Pediatrics):223.

[7] Bovée JVMG, Hogendoorn PCW: Multiple osteochondromas. In World Health Organization classification of tumors. Pathology and genetics of tumors of soft tissue and bone. Edited by: Fletcher CDM, Unni KK and Mertens F. Lyon, IARC Press; 2002:360-62.

[8] Bovée JVMG. Multiple osteochondromas, Review. Journal of Rare Diseases 2008;3:3. PMid:18271966 http://dx.doi.org/10.1186/1750-1172-3-3

[9] Giudicissi-Filho M MD, M. de Holanda CV MD, Borba LAB MD, A Rassi-Neto, MD, CAA Ribeiro, MD, JG, alves de Oliveira, MD: Cervical spinal cord compression due to an osteochondroma in hereditary multiple exostosis: Case report and review of the literature. Surg. Neurol. 66 (2006) S3:7-S3:11

[10] Chooi YS, Siow YS, Chong CS. Cervical myelopathy caused by an exostosis of the posterior arch of C1. J Bone Joint Surg Br 2005;87(2):257-59. http://dx.doi.org/10.1302/0301-620X.87B2.15560

[11] Robbins SE, Laitt RD, Lewis T. Hereditary spinal osteochondromas in diaphyseal aclasia. Neuroradiology 1996;38(1):59-61. PMid:8773280 http://dx.doi.org/10.1007/BF00593223

[12] Jaffe HL. Hereditary multiple exostosis. Arch Pathol 1943;36:335-57.

[13] Madigan R, Worrall T, McClain EJ. Cervical cord compression inhereditary multiple exostosis. Review of the literature and report of a case. J Bone Joint Surg Am 1974;56(2):401-404. PMid:4548904

[14] Gottlieb A, Severi P, Ruelle A, Lasio G. Exostosis as a cause of spinal cord compression. Surg Neurol 1986;26(6):581-84. http://dx.doi.org/10.1016/0090-3019(86)90345-9

[15] Old WL, Triplett JN. Osteochondroma with thoracic cord compression in hereditary multiple exostoses: A case report. Virginia Med 1979;106:303-306.

[16] Reid J. Case of disease of the spinal cord from an exostosis of the second cervical vertebra. Lond Edinb Mon J Med Sci 1843;3:194-98.

[17] Ochsner EH, Rothstein T. Multiple exostoses including an exostosis within the spinal canal with surgical and neurological observations. Ann Surg 1907;46:608-16. PMid:17862053 http://dx.doi.org/10.1097/00000658-190710000-00012

[18] Oberndorf CP. A case of multiple exostoses coupled with syringomyelia. NY Med J 1910;91:479-83.

[19] Slepian A, Hamby WB. Neurologic complications associated with hereditary deformity chondrodysplasia. Review of the literature and a report on two cases occurring in the same family. J Neurosurg 1951;8:529-35. PMid:14880944 http://dx.doi.org/10.3171/jns.1951.8.5.0529

[20] Rose EF, Fekete A. Odontoid osteochondroma causing sudden death. Am J Clin Pathol 1964;42:606-609. PMid:14239437

[21] Carmel PW, Cramer FJ. Cervical cord compression due to exostosis in a patient with hereditary multiple exostoses. Case report. J Neurosurg 1968;28(5):500-503. PMid:5301711 http://dx.doi.org/10.3171/jns.1968.28.5.0500

[22] Chiurco AA. Multiple exostoses of bone with fatal spinal cord.

[23] Compression; report of a case and brief review of the literature. Neurology 1970;20(3):275-78. PMid:5308715

[24] Sawada M. Case report of hereditary multiple exostosis with symptoms of cervical spinal cord compression. Seikei Geka 1970;21(4):287-90. PMid:5311016

[25] Vinstein AL, Franken Jr EA. Hereditary multiple exostoses. Report of a case with spinal cord compression. Am J Roentgenol Radium Ther Nucl Med 1971;112(2):405-407. PMid:5314313

[26] Blaauw G. Osteocartilaginous exostosis of the spine. In: Vinken PJ, Bruyn GW, editors. Handbook of clinical neurology, vol. 19. Amsterdam7 North Holland Publishing; 1975:p313-19.

[27] Jorge Facure J, Facure NO, Castro LF. Exostose multipla hereditaria com compressao medular. Arq Neuropsiquiatr 1975;33(2):151-55. PMid:1080045

[28] Roman G. Hereditary multiple exostoses. A rare cause of spinal cord compression. Spine 1978;3(3):230-33. PMid:309661 http://dx.doi.org/10.1097/00007632-197809000-00008

[29] Ferrari G, Taddei L, Vivenza C, Rossi G. Paraparesis in hereditary multiple exostoses: Case report. Neurology 1979;29(7):973-77. PMid:381970 
[30] Singh DS, Rao SS, Sharma S, Srivastava KK, Yadav SS. Cervical cord compression from multiple hereditary exostoses. J Assoc Physicians India 1980;28(12):535-37. PMid:6971865

[31] Palmer FJ, Blum PW. Osteochondroma with spinal cord compression: Report of three cases. J Neurosurg 1980;52(6):842-45. PMid:7381544 http://dx.doi.org/10.3171/jns.1980.52.6.0842

[32] Misra UK, Nag D, Dave VS, Shukla R, Kar AM. Cervical cord compression due to chondromatous change in a patient with metaphysical aclasis. J Neurol Neurosurg Psychiatry 1983;46(12):1155-57. PMid:50411 http://dx.doi.org/10.1136/jnnp.46.12.1155

[33] Omori M, Sakate Y, Tamura Y, Katayama M, Furukawa Y, Saito S. Cervical and compression due to exostosis in a patient with multiple exostosis: A case report. Seikei Geka 1983;34:1354-58.

[34] O’Connor GA, Roberts TS: Spinal cord compression by an osteochondroma in a patient with multiple osteochondromatosis. Case report. J Neurosurg 1984;60(2):420-43. PMid:6693968 http://dx.doi.org/10.3171/jns.1984.60.2.0420

[35] Johnston II CE, Sklar F: Multiple hereditary exostoses with spinal cord compression. Orthopedics 1988;11(8):1213-16. PMid:3262217

[36] Tully RJ, Pickens J, Oro J, Levine C.: Hereditary multiple exostoses and cervical cord compression: CT and MR studies. J Comput Assist Tomogr 1989;13(2):330-33. PMid:2784452 http://dx.doi.org/10.1097/00004728-198903000-00029

[37] Nunez DA, Graham HK, Fixsen JA. Cervical cord compression and femoral neuropathy in hereditary multiple exostoses. J Neurol Neurosurg Psychiatry 1990;53(5):439. PMid:50411 http://dx.doi.org/10.1136/jnnp.53.5.439

[38] Anton J, Sainz C, Perez E, Moreno L, Ojeda J: Compresion medular a nivel de C6 como primer signo de exostosis multiple hereditaria. Rev Clin Esp 1990;186(2):88-90. PMid:2330442

[39] Moriwaka F, Hozen H, Nakane K, Sasaki H, Tashiro K, Abe H: Myelopathy due to osteochondroma: MR and CT studies. J Comput Assist Tomogr 1990;14(1):128-30. PMid:2298977 http://dx.doi.org/10.1097/00004728-199001000-00025

[40] Bhojraj SY, Panjwani JS. A new management approach to decompression, posterior stabilization, and fusion for cervical laminar exostosis with cord compression in a case of diaphyseal aclasis. Case report and review of the literature. Spine 1993;18(10):137-39. PMid:8211373 http://dx.doi.org/10.1097/00007632-199308000-00021

[41] Eder HG, Oberbauer RW, Ranner G: Cervical cord compression in hereditary multiple exostoses. J Neurosurg Sci 1993;37(1):53-56. PMid:8366369

[42] Barros Filho TE, Oliveira RP, Taricco MA, Gonzalez CH: Hereditary multiple exostoses and cervical ventral protuberance causing dysphagia. A case report. Spine 1995;20(14):1640-62. http://dx.doi.org/10.1097/00007632-199507150-00015

[43] Ergun R, Okten AI, Beskonakli E, Akdemir G, Taskin Y: Cervical laminar exostosis in multiple hereditary osteochondromatosis: Anterior stabilization and fusion technique for preventing instability. Eur Spine J 1997;6(4):2676-79. http://dx.doi.org/10.1007/BF01322449

[44] MikawaY, Watanabe R, NakashimaY, Hayashida T: Cervical spinal cord compression in hereditary multiple exostoses. Report of a case and a review of the literature. Arch Orthop Trauma Surg 1997;116(1-2):112-15. PMid:9006779 http://dx.doi.org/10.1007/BF00434114

[45] Oga M, Nakatani F, Ikuta K, Tamaru T, Arima J, Tomishige M: Treatment of cervical cord compression, caused by hereditary multiple exostosis, with laminoplasty: A case report. Spine 2000;25(10):1290-92.

PMid:10806509http://dx.doi.org/10.1097/00007632-200005150-00016

[46] Cirak B, Karabulut N, Palaoglu S: Cervical osteochondroma as a cause of spinal cord compression in a patient with hereditary multiple exostoses: Computed tomography and magnetic resonance imaging findings. Australas Radiol 2002;46(3):309-11. PMid:12196244 http://dx.doi.org/10.1046/j.1440-1673.2002.01067.x

[47] Rohde V, Reinacher P, Patz E, Sellhaus B, Gilsbach JM: Spinal cord compression by a cervical oseteocartilaginous exostosis: Surgical strategy aspects. Z Orthop Ihre Grenzgeb 2004;142(2):179-83. PMid:15106063 http://dx.doi.org/10.1055/s-2004-818785

[48] Miyamoto K, Sakaguchi Y, Hosoe H, et al: Tetraparesis due to exostotic osteochondroma at upper cervical cord in a patient with multiple exostoses-mental retardation syndrome (Lange Giedion syndrome). Spinal Cord 2005;43(3):190-94. PMid:15583707 http://dx.doi.org/10.1038/sj.sc.3101690

[49] Roach J W, Joshua W.B. Faulkner K D, Faulkner N D: Involvement of the Spine in Patients with Multiple Hereditary Exostoses. J Bone Joint Surg Am. 2009;91:1942-48. PMid:19651953 http://dx.doi.org/10.2106/JBJS.H.00762

[50] Marchand EP, Villemure JG, Rubin J, Robitaille Y, Ethier R: Solitary osteo-Chondroma of the thoracic spine presenting as spinal cord compression: A case Report. Spine 1986;11:1033-50. PMid:3576338 http://dx.doi.org/10.1097/00007632-198612000-00013

[51] Pierz A, Stieber JR, Kusumi MDK, Dormans JP: Hereditary multiple exostoses: One center’s experience and review of etiology. Clin. Orthop. Relat. Res 401, pp49-59. PMid:12151882 http://dx.doi.org/10.1097/00003086-200208000-00008

[52] Vanhoenacker FM, Van Hul W, Wuyts W, Willems PJ, De Schepper AM: Hereditary multiple exostoses: From genetics to clinical syndrome and complications. Eur. J. Radiol. 40 (2001) 208-17. http://dx.doi.org/10.1016/S0720-048X(01)00401-6 